SUSTAINABLE FORESTRY

COLLECTION 65-66, 2012
ODRŽIVO ŠUMARSTVO

ZBORNIK RADOVA 65-66, 2012

UDK $630 * 416.5+630 * 443.3=111$

Original scientific paper

\title{
MANALYSIS OF THE IMPACT OF INJURIES CAUSED BY THE INFLUENCE OF MECHANICAL AND ABIOTIC FACTORS ON THE OCCURRENCE OF HARMFUL FUNGAL ORGANISMS
}

\author{
Miroslava MARKOVIC ${ }^{1}$, Snezana RAJKOVIC ${ }^{1}$, Radoslav RAJKOVIC ${ }^{2}$
}

\begin{abstract}
The research described in this paper is focused on the occurrence of pathogenic microorganisms on beech trees relative to the presence of tree injuries, with the aim to ensure protection and preservation of this species in Serbia. The research was conducted in eastern Serbia, in a hillside beech forest Fagetum moesiacae submontanum of generative origin. The testing was carried out on two sites over 51 testing plots, with a total of 829 trees and 21 species of identified fungi. On the first site it was found that the appearance of fungi primarily depends on the presence of mechanical damage on trees (as much as $73.46 \%$ ), while the presence of abiotic damage has almost no bearing (only $3.21 \%$ ). On the second site there was a strong correlation link between the occurrence of fungi and presence of mechanical damage - $51.88 \%$, as well as between the fungi and abiotic damage $-47.96 \%$. The health condition of high beech stands was found to be heavily dependent on careful and proper manipulation during harvesting, while each injury inflicted on a beech live tree during logging opens the door to infection with pathogenic microorganisms.
\end{abstract}

\footnotetext{
${ }^{1} \mathrm{PhD}$ Miroslava Markovic, Research Associate, Institute for Forestry, Kneza Viseslava 3, 11030 Belgrade, Serbia, Mob. tel.: +381691999116, Fax.: +381112545969, Email: mira013@gmail.com

${ }^{1} \mathrm{PhD}$ Snezana Rajkovic, Principal Research Fellow, Institute for Forestry, Kneza Viseslava 3, 11030 Belgrade, Serbia

${ }^{2}$ MSc Radoslav Rajkovic, Research Assistant, University of Belgrade, Faculty of Mechanical Engineering, Queen Mary 16, 11030 Belgrade, Serbia

* Acknowledgement: The study was carried out within the Project TP-31070: "The development of technological methods in forestry in order to attain optimal forest cover", financed by the Ministry of Education and Science of the Republic of Serbia within the framework of integrated and interdisciplinary research for the period $2011-2014$.
} 
Key words: injuries, environmental factors, fungi, beech forests

\section{АНАЛИЗА УТИЦАЈА ОЗЛЕДА ПРОУЗРОКОВАНИХ ДЕЈСТВОМ МЕХАНИЧКИХ И АБИОТИЧКИХ ФАКТОРА НА ПОЈАВУШТЕТНИХ ГЉИВИЧНИХ ОРГАНИЗАМА}

Извод: У раду је истраживан аспект појаве патогених микроорганизама на буковом дрвету у односу на присуство озледа на стаблима, у ициљу заштите и очувања ове врсте у Србији. Истраживања су вршена у источној Србији, у брдској иуми букве Fagetum тоеsiacae submontanum, генеративног порекла. Испитивањем је обухваћено два локалитета на 51 огледној париели, са укупно 829 стабала и констатовано је присуство 21 врста гљива. На првом локалитету констатовано је да појава гљива првенствено зависи од присуства механичких оштећења на стаблима (чак 73.46\%), а готово уопште није у вези са присуством абиотичких оштећена (свега 3.21\%). На другом локалитету постоји јака корелачиона веза између појаве гљива и присуства механичких оштећења - 51.88\%, као и између гљива и абиотичких оштећења - 47.96\%. Констатовано је да за здравствено стање високих букових састојина изузетан значај има пажљьио и правилно манипулисање приликом сече, а свака озледа на буковим дубећим стаблима почињена при сечи је отворен пут за заразу патогеним микроорганизмима.

Кључне речи: оштећења, спољна средина, гљиве, букове шуме

\section{INTRODUCTION}

The strategy of preserving the biodiversity and genetic resources of economically most valuable species of tress dictates that Serbia's forestry should primarily be concerned with preservation of the abundance of natural forests as a national wealth (Milovanovic et al 2004). According to the internationally adopted definition, sustainable forest management means "the stewardship and use of forests and forest lands in a way, and at a rate, that maintains their biodiversity, productivity, regeneration capacity, vitality and their potential to fulfil relevant ecological, economic and social functions, and that does not cause damage to other ecosystems" (MCPFE, Helsinki 1993, as cited in Medarevic et al 2008).

Serbia's forest area relative to the global aspect is close to the world's level of $30 \%$, but significantly below the European average of $46 \%$. Out of the total $29.1 \%$ of forest area in Serbia, $7.1 \%$ is in Vojvodina whereas $37.6 \%$ of forests are located in Central Serbia (Bankovic et al 2009). The national inventory of Serbia's forests in the total volume and bulk growth is dominated by beech, whose presence amounts to $42.4 \%$, or $32.3 \%$ (Bankovic et al 2000).

Due to their presence in the forest reserves of Serbia, beech forests undoubtedly have the greatest significance. We can therefore conclude, quite justifiably, that management of beech forests is a much more complex and difficult task compared to management of any other tree species. In addition, available references most frequently speak of the quality of tall beech forests in descriptive and general terms - that it is unsatisfactory and in need of improvement (Stojanovic \& Krstic 2003, Koprivica et al 2009). 
The biological properties, ecological demands, natural distribution, stewardship values and generally beneficial functions of beech forests, along with their structure, make beech the basic tree species for Serbian forestry (Vuckovic et al 2005), although the use of beech lumber on a wider scale is limited by its short lifespan.

Beech wood is vulnerable and represents an excellent base for development of numerous parasitic and saprophytic organisms, among which primarily parasitic fungi and harmful insects. In beech coppice forests in Serbia, the total of 147 species of fungi were found on beech trees, out of which 33 species occur on crowns, fruits and young crop, 56 species occur on leaves and bark of the branches and the trunk, whereas 58 species of fungi cause rot and coloration of wood (Karadzic \& Milijasevic 2005).

The cause of beech forests dieback is a consequence of simultaneous negative impact of climatic (climate changes), management and biotic factors. Among these a special place belongs to man, whose irrational exploitation of beech forests resulted in Serbia's area under forest being cut almost in half. Deforestations of beech woodland that occurred in the past (in particular immediately after World War II) were not at all conducted as regeneration harvests, but almost exclusively for exploitation purposes. As a consequence of such management practices, forests have become extremely sensitive to harmful effects of numerous abiotic and biotic factors, notably parasitic fungi and harmful insects among the latter. The problem of protection of beech forests is further complicated by the occurrence of dangerous diseases and a large number of wood destructors that start their development as parasites on living trees and continue as saprophytes on timber (Tabakovic-Tosic \& Markovic 2003, Miletic et al 2006, Markovic et al 2011a, Markovic et al 2011b).

This paper researched one aspect of occurrence of pathogenic microorganisms on beech trees, with the aim to contribute to the most rational approach to use of beech timber while preserving the beech stands in Serbia to the maximum extent.

\section{MATERIAL AND METHODS}

The sites selected for research were the ones on which the observation method revealed a large number of injuries on trees. The paper provides an analysis of the impact of tree injuries on occurrence of pathogenic and epixylic fungi on live trees in beech woodlands.

The research was carried out in the forest holding "Severni Kucaj" in Kucevo, forest administration Kucevo, Eastern Serbia, in a hillside forest of Fagetum moesiacae submontanum beech of generative origin. The first tested site was located in the administration unit Majdan Kucajna, division 33. The second site was in administration unit Crni Vrh, division 42, sections $a$ and $b$. The research included the total of 829 beech trees on 51 test plots.

The $500 \mathrm{~m}^{2}$ trial experimental plots were circular, placed in the stands at $100 \times 100 \mathrm{~m}$ distances (according to the method described by Koprivica et al 2008). Each experimental plot included between 4 and 24 trees on site I, and 
between 8 and 27 trees on site II. Injuries noted on each tree were classified as mechanic (injuries from felling and hauling during harvest) and abiotic (injuries from wind, snow, ice, frost and excessive insulation that caused bark inflammation). The methods used were those described by Koprivica \& Matovic, 2005, Markovic et al 2007. In addition, any presence of pathogenic and epyxilic fungi on trees was also noted. On the basis of the received data, statistical analysis was conducted in order to determine the correlation link.

\section{RESULTS AND DISCUSSION}

Table 1 presents an overview of the fungi identified on site 1 according to their frequency of occurrence. It is evident from the table that the first 4 fungi are present in all experimental plots (noted on $12.6 \%$ to $29 \%$ of all trees), whereas the presence of the latter 8 fungi was noted, on t he average, in only 4 plots and no more than $0.3 \%$ to $0.9 \%$ of trees. The fungi with ordinal numbers 5 through 9 are present on over $50 \%$ of experimental plots (or $6.5 \%$ to $11.1 \%$ of trees), while the fungi with ordinal numbers 8 through 13 were identified on less than $50 \%$ of the plots and spread on $1 \%$ to $20 \%$ of the tested trees.

Table 1 and table 2 presents fungi classified according to their significance, where those with 3 stars represent dangerous fungi with high significance, the fungi with 2 stars have medium significance, the fungi with one star have low significance, and those without stars have no significance.

Table 1. Fungi identified on site I-Administration unit Majdan Kucajna, division 33

\begin{tabular}{|c|c|c|c|c|}
\hline $\begin{array}{l}\text { Ordinal } \\
\text { number } \\
\text { of fungus }\end{array}$ & Type of fungus & $\begin{array}{l}\text { Significance of } \\
\text { fungus }\end{array}$ & $\begin{array}{c}\text { \% plots on } \\
\text { which the } \\
\text { fungus is } \\
\text { present }\end{array}$ & $\begin{array}{l}\% \text { trees on } \\
\text { which the } \\
\text { fungus is } \\
\text { present }\end{array}$ \\
\hline 1 & Apiognomonia errabunda & $* * *$ & 100.0 & 29.0 \\
\hline 2 & Coriolus sp. & $* *$ & 100.0 & 24.6 \\
\hline 3 & Hypoxylon sp. & $* *$ & 100.0 & 8.9 \\
\hline 4 & Stereum sp. & $* *$ & 100.0 & 12.6 \\
\hline 5 & Diatrype stigma & $\%$ & 65.2 & 11.1 \\
\hline 6 & Fomes fomentarius & $* * *$ & 57.0 & 6.5 \\
\hline 7 & Trametes sp. & $* *$ & 52.2 & 8.6 \\
\hline 8 & Diatrype disciformis & $* *$ & 47.8 & 20.9 \\
\hline 9 & Nectria galligena & $* * *$ & 30.4 & 4.0 \\
\hline 10 & Armillaria mellea & $* * *$ & 26.0 & 1.2 \\
\hline 11 & Lenzites trabaea & $* *$ & 17.4 & 1.8 \\
\hline 12 & Nectria coccinea & $* * *$ & 8.7 & 1.2 \\
\hline 13 & Fomes igniarius & $* *$ & 8.7 & 1.5 \\
\hline 14 & Pleurotus ostreatus & $* * *$ & 4.3 & 0.6 \\
\hline 15 & Poria obliqua & $* * *$ & 4.3 & 0.3 \\
\hline
\end{tabular}




\begin{tabular}{|c|l|c|c|c|}
\hline 16 & Dedalea quercina & $* *$ & 4.3 & 0.9 \\
\hline 17 & Exidia recisa & $*$ & 4.3 & 0.3 \\
\hline 18 & Hydnum coraloides & $*$ & 4.3 & 0.3 \\
\hline 19 & Auricullaria auricila judae & - & 4.3 & 0.3 \\
\hline 20 & Auricullaria mesenterica & - & 4.3 & 0.3 \\
\hline 21 & Bulgaria polymorpha & - & 4.3 & 0.6 \\
\hline
\end{tabular}

Under the classification proposed by Karadzic 2003, the present fungi were classified as follows:

*** fungi with high significance (the highest significance is given to fungi that act that both as parasites and saprophytes, i.e. whose activity starts on standing, live trees and then persists on dead trees, following the harvest). These species of epyxilic fungi demonstrate a very high level of destruction and degrade primarily lignin, as well as cellulose and hemicelluloses, but to a lesser degree. Among the identified fungi, this group comprises Armillaria mellea, Fomes fomentarius, Pleurotus ostreatus and Poria obliqua. Besides the above-named wood-decay fungi, this group also includes the following pathogenic fungi: Apiognomonia errabunda, Nectria coccinea and Nectria galligena).

** fungi with medium significance (this group comprises the fungi that cause a somewhat lower degree of destruction, but appear on both injured, weakened trees and the freshly harvested ones). This group is represented by Coriolus versicolor, Dedalea quercina, Diatrype disciformis, Hypoxylon sp., Stereum sp. and Trametes sp.

* fungi with low significance (this group comprises the fungi that appear on rotting trees, frequently causing their complete degradation). Among the identified fungi, this group includes Exidia recisa, Hydnum sp. and Diatrype stigma.

- fungi with no significance (representatives of this group identified on the tested sites include Auricullaria auricula judae, Auricullaria mesenterica and Bulgaria polymorpha).

Table 2. Fungi identified on site II - Administration unit Crni Vrh, division 42, sections $a, b$

\begin{tabular}{|c|l|c|c|c|}
\hline $\begin{array}{c}\text { Ordinal } \\
\text { number } \\
\text { of } \\
\text { fungus }\end{array}$ & \multicolumn{1}{|c|}{ Type of fungus } & $\begin{array}{c}\text { Significance of } \\
\text { fungus }\end{array}$ & $\begin{array}{c}\% \text { plots on } \\
\text { which the } \\
\text { fungus is } \\
\text { present }\end{array}$ & $\begin{array}{c}\% \text { trees on } \\
\text { which the } \\
\text { fungus is } \\
\text { present }\end{array}$ \\
\hline 1 & Coriolus sp. & $* *$ & 100.0 & 18.3 \\
\hline 2 & Apiognomonia errabunda & $* * *$ & 82.0 & 15.0 \\
\hline 3 & Hypoxylon sp. & $* * *$ & 78.6 & 6.5 \\
\hline 4 & Nectria coccinea & $* * *$ & 64.3 & 7.1 \\
\hline 5 & Nectria galligena & $*$ & 35.6 & 6.5 \\
\hline 6 & Diatrype stigma & & & 5.7 \\
\hline
\end{tabular}




\begin{tabular}{|c|l|c|c|c|}
\hline 7 & Fomes fomentarius & $* * *$ & 21.0 & 2.2 \\
\hline 8 & Hydnum coraloides & $*$ & 14.3 & 0.8 \\
\hline 9 & Stereum sp. & $* *$ & 10.7 & 1.2 \\
\hline 10 & Diatrype disciformis & $* *$ & 7.1 & 1.4 \\
\hline 11 & Armillaria mellea & $* * *$ & 7.0 & 0.6 \\
\hline 12 & Dedalea quercina & $* *$ & 3.6 & 0.2 \\
\hline
\end{tabular}

Table 3 presents the testing results for the total number of the present fungi and the total number of mechanical and abiotic damage on site II.

One of the most significant fungi identified on the tested sites is Nectria coccinea (Pers. Ex Fr.) Fries., which together with the insect Cryptococcus fagisuga Lind. causes the so-called "beech bark disease". On site I, this fungus was found on $1.2 \%$ of trees or on 3 experimental plots (1,3 and 9), whereas on site II its spread was much greater and covered $7.1 \%$ of trees or almost two-thirds of experimental plots. This disease is lately being regarded as a major factor compromising normal development of beech trees, which merits special attention given the fact that it is spreading over ever-larger areas.

Table 3. Overview of attack by fungi and injuries on beech trees on site IAdministration unit Majdan Kucajna, division 33

\begin{tabular}{|c|c|c|c|c|c|c|c|}
\hline \multirow[b]{2}{*}{ 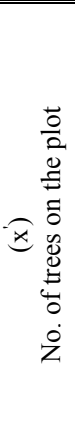 } & \multicolumn{3}{|c|}{ Number of fungi found } & \multirow[b]{2}{*}{ 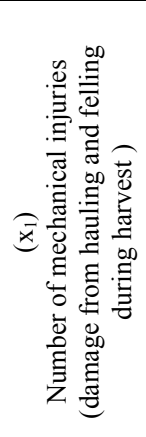 } & \multirow[b]{2}{*}{ 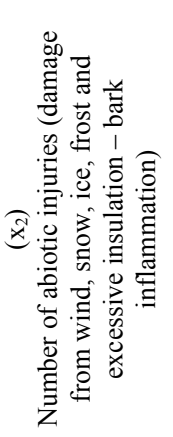 } & \multirow[b]{2}{*}{ 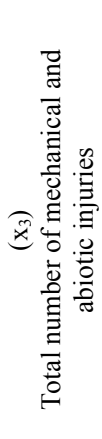 } & \multirow[b]{2}{*}{ 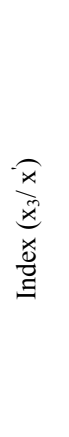 } \\
\hline & 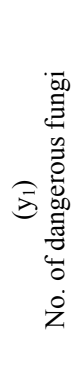 & 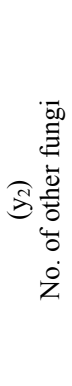 & 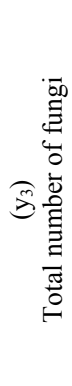 & & & & \\
\hline 12 & 1 & 3 & 4 & 2 & 3 & 5 & 0.42 \\
\hline 24 & 1 & 4 & 5 & 3 & 4 & 7 & 0.29 \\
\hline 9 & 1 & 3 & 4 & 2 & 3 & 5 & 0.56 \\
\hline 11 & 1 & 3 & 4 & 1 & 3 & 4 & 0.36 \\
\hline 16 & 1 & 5 & 6 & 8 & 1 & 9 & 0.56 \\
\hline 9 & 1 & 4 & 5 & 6 & 2 & 8 & 0.89 \\
\hline 16 & 4 & 6 & 10 & 15 & 6 & 21 & 0.06 \\
\hline 12 & 4 & 6 & 10 & 20 & 9 & 29 & 2.42 \\
\hline 23 & 6 & 9 & 15 & 27 & 4 & 31 & 1.35 \\
\hline 15 & 1 & 6 & 7 & 3 & 1 & 4 & 0.27 \\
\hline 21 & 2 & 6 & 8 & 17 & 9 & 26 & 1.24 \\
\hline 18 & 3 & 6 & 9 & 21 & 3 & 24 & 1.33 \\
\hline 8 & 1 & 5 & 6 & 14 & 2 & 16 & 2.00 \\
\hline 11 & 2 & 6 & 8 & 15 & 3 & 18 & 1.64 \\
\hline 19 & 2 & 6 & 8 & 11 & 10 & 21 & 1.11 \\
\hline 4 & 1 & 5 & 6 & 4 & 1 & 5 & 1.25 \\
\hline 15 & 3 & 5 & 8 & 16 & 42 & 20 & 1.33 \\
\hline 9 & 1 & 4 & 5 & 9 & 6 & 11 & 1.22 \\
\hline 23 & 4 & 8 & 12 & 19 & 7 & 25 & 1.09 \\
\hline
\end{tabular}




\begin{tabular}{||c||c|c|c||c|c|c||c||}
\hline 8 & 2 & 4 & 6 & 7 & 3 & 14 & 1.75 \\
\hline 8 & 1 & 5 & 6 & 14 & 3 & 17 & 2.12 \\
\hline 17 & 4 & 6 & 10 & 12 & 8 & 20 & 1.18 \\
\hline 16 & 3 & 7 & 10 & 23 & 4 & 27 & 1.69 \\
\hline
\end{tabular}

Measures undertaken against this fungus are classified into several categories:

- biological preventive measures, including use of predators and super-parasites against insects (prior to infection with fungus),

- bio-control of the fungus by means of antagonists (once the infection occurs),

- silvicultural measures - removal of diseased trees (in advanced stages of the infection),

- chemical measures, which are non-economical for forests and thus applied only to parks and alleys of trees.

It is important to note that following the infection of beech trees with this fungus, the necrotic bark sections very quickly get infested by wood-decaying fungi and wood-destroying insects, which also play a role in rapid tree decay and extinction of beech trees (Karadzic 2003, Ivkovic et al 2007).

The data presented in Table 3 served as basis for performance of a statistical analysis - simple and multiple linear regression between all pairs in the presented columns, and correlation matrixes made between columns $x^{\prime}, y_{1}, y_{2}$ and $\mathrm{y}_{3}$, as well as columns $\mathrm{x}_{1}, \mathrm{x}_{2}, \mathrm{x}_{3}$ and $\mathrm{x}_{3} / \mathrm{x}^{\prime}$. The correlation analysis clearly demonstrates that in all cases there is a link between the number of trees ( $x$ ) and other columns. Next, there is a correlation link between the number of dangerous fungi $\left(\mathrm{y}_{1}\right)$ and other columns, with the exception of abiotic injuries $\left(\mathrm{x}_{2}\right)$ and index representing a quotient between the total number of injuries and the number of trees $\left(x_{3} / x^{\prime}\right)$. The same applies to columns $y_{2}$ (other fungi), $y_{3}$ (total number of fungi) and $x_{1}$ (mechanical injuries). Column $x_{2}$ has no correlation links with any other column, whereas $x_{3}$ (the total number of mechanical and abiotic injuries) has links to all columns except abiotic injuries $\left(\mathrm{x}_{2}\right)$. Column $\mathrm{x}_{3} / \mathrm{x}^{\prime}$ (index) is not linked to other columns, except to columns $\mathrm{x}_{1}$ and $\mathrm{x}_{3}$ (mechanical injuries and total number of injuries).

This practically means that, on site I, the occurrence of fungi (both dangerous and other) - column $\mathrm{y}_{3}$ is primarily contingent upon the presence of mechanical injuries - $\mathrm{x}_{1}$ (as much as $73.46 \%$ ), while the remaining $26.54 \%$ depends on other factors - tree condition (susceptibility to disease), position inside the stand (open trees or within a dense canopy, land elevation, geological base, etc.), climatic conditions during the year that may or may not favour the development of fungi, etc. On the other hand, statistical analysis of the data received from site I shows that the occurrence of fungi is not linked to damage caused by activity of abiotic factors (the correlation link is very low at 3.21\%).

Therefore, careful and proper handling of trees during felling is critical for the health condition of tall beech stands. Every injury sustained by live beech trees during felling opens the door to infection by pathogenic microorganisms.

Condition on site II is presented in Table 4, which was the basis for performance of a statistical analysis - simple and multiple linear regression 
between all pairs in the presented columns and correlation matrixes made between columns $\mathrm{x}^{\prime}, \mathrm{y}_{1}, \mathrm{y}_{2}$ and $\mathrm{y}_{3}$, as well as columns $\mathrm{x}_{1}, \mathrm{x}_{2}, \mathrm{x}_{3}$ and $\mathrm{x}_{3} / \mathrm{x}^{\prime}$.

Statistical analysis of the obtained data demonstrated that on this site there was a significant statistical link between all presented columns, as well as between the number of abiotic injuries and occurrence of fungi. While this was not the case on the previous site, it appeared here as a consequence of a large number of injuries. The strongest correlation link was the one between the total number of fungi and mechanical injuries (columns $\mathrm{y}_{3}$ and $\mathrm{x}_{1}$ ), amounting to $51.88 \%$. Another strong link existed between the total number of fungi and abiotic injuries (columns $\mathrm{y}_{3}$ and $\mathrm{x}_{2}$ ), only slightly weaker than the previous one at $47.96 \%$. The links between the number of dangerous and other fungi $\left(\mathrm{y}_{1}, \mathrm{y}_{2}\right)$ and mechanical and abiotic injuries $\left(\mathrm{x}_{1}, \mathrm{x}_{2}\right)$ were significant, ranging from $26.70 \%$ and $36.47 \%$, where the links between the fungi and mechanical injuries were stronger by roughly 2 to $5 \%$ than the links between the occurrence of fungi and abiotic injuries.

Table 4. Overview of attack by fungi and injuries on beech trees on site IIAdministration unit Crni Vrh, division 42, sections $a, b$

\begin{tabular}{|c|c|c|c|c|c|c|c|}
\hline \multirow[b]{2}{*}{ 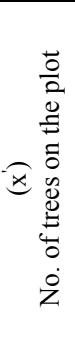 } & \multicolumn{3}{|c|}{ Number of fungi found } & \multirow[b]{2}{*}{ 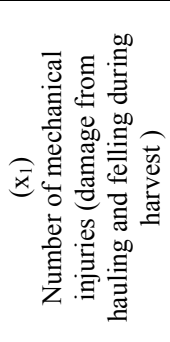 } & \multirow[b]{2}{*}{ 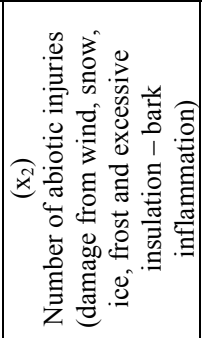 } & \multirow[b]{2}{*}{ 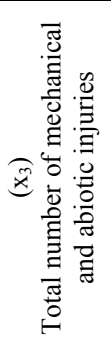 } & \multirow[b]{2}{*}{ 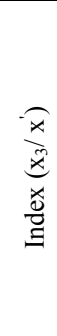 } \\
\hline & 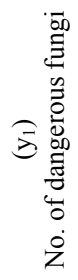 & 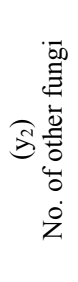 & 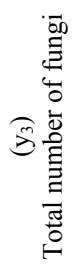 & & & & \\
\hline 20 & $\overline{5}$ & 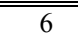 & 111 & $\bar{~} 16$ & 42 & $\overline{58}$ & $\bar{~} 2.90$ \\
\hline 27 & 3 & 3 & 6 & 12 & 7 & 19 & 0.70 \\
\hline 22 & 5 & 3 & 8 & 16 & 34 & 50 & 2.27 \\
\hline 20 & 4 & 2 & 6 & 4 & 34 & 38 & 1.90 \\
\hline 21 & 3 & 3 & 6 & 10 & 17 & 27 & 1.29 \\
\hline 9 & 1 & 2 & 3 & 4 & 8 & 12 & 1.33 \\
\hline 11 & 0 & 3 & 3 & 7 & 7 & 14 & 1.27 \\
\hline 14 & 0 & 2 & 2 & 2 & 7 & 9 & 0.64 \\
\hline 22 & 3 & 2 & 5 & 5 & 7 & 12 & 0.54 \\
\hline 17 & 4 & 2 & 6 & 8 & 37 & 86 & 5.06 \\
\hline 10 & 1 & 2 & 3 & 2 & 19 & 19 & 1.90 \\
\hline 12 & 2 & 2 & 4 & 8 & 14 & 22 & 1.83 \\
\hline 16 & 2 & 2 & 4 & 10 & 7 & 17 & 1.06 \\
\hline 23 & 3 & 2 & 5 & 10 & 3 & 13 & 0.56 \\
\hline 21 & 3 & 2 & 5 & 14 & 2 & 16 & 0.76 \\
\hline 25 & 2 & 5 & 7 & 16 & 27 & 43 & 1.72 \\
\hline 19 & 1 & 3 & 4 & 11 & 9 & 20 & 1.05 \\
\hline 14 & 1 & 2 & 3 & 3 & 11 & 14 & 1.00 \\
\hline 23 & 4 & 2 & 6 & 14 & 10 & 24 & 1.04 \\
\hline 19 & 3 & 2 & 5 & 5 & 17 & 22 & 1.16 \\
\hline 11 & 0 & 2 & 2 & 6 & 8 & 14 & 1.27 \\
\hline 23 & 3 & 2 & 5 & 1 & 18 & 19 & 0.83 \\
\hline 20 & 1 & 2 & 3 & 3 & 9 & 12 & 0.60 \\
\hline 20 & 0 & 2 & 2 & 1 & 3 & 4 & 0.20 \\
\hline 8 & 0 & 2 & 2 & 1 & 15 & 16 & 2.00 \\
\hline 26 & 3 & 2 & 5 & 12 & 20 & 32 & 1.23 \\
\hline 18 & 3 & 2 & 5 & 15 & 15 & 30 & 1.67 \\
\hline 13 & 3 & 2 & 5 & 7 & 8 & 15 & 1.15 \\
\hline
\end{tabular}


This means that the occurrence of fungi (both dangerous and other fungi) on the second site - column $\mathrm{y}_{3}$ - was directly linked to the presence of mechanical and abiotic injuries - $\mathrm{x}_{1}$ and $\mathrm{x}_{2}$. In other words, the results obtained through comparative analysis of sites I and II lead to conclusion that the number of injuries is in fact the determining factor linking the occurrence of fungi and damage to trees. On sites with fewer injuries the correlation links between the occurrence of fungi and the injuries on trees are less strong, and vice versa.

It is a well-known fact that health status of the stands is contingent upon a large number of factors, among which year-round climatic conditions must be considered as one of the most critical. Rainy, humid and relatively warm weather favours the activity of the fungi and increases the yield, and thus enables not only faster colonization by the fungi but also more precise identification of the existing microflora. It should also be noted that diagnosis of the disease is greatly impeded by long incubation of the fungi colonizing vital trees, while primary symptoms appear on the surface only after several years of attack (reproductive organs visible carpophores may not appear at all or their appearance might be extended over a number of years). In addition to an accurate diagnosis, it is essential to make a precise prognosis of the dynamics of development of pathological processes in the plant. However, this prognosis cannot be determined with any reliable level of accuracy for the upcoming calendar years, as climatic conditions are a determining factor for the development of the infection. It is thus possible to make only a rough prognosis, based on mapping the parts of the forest under attack according to the destructor species and attack intensity, and use it as basis for planning the sanitary and silvicultural activities.

Sanitation felling and other phytosanitary measures, which may or may not be carried out in forests, certainly have a great impact on general health condition of the stands. Proper stewardship can minimize the existing infections and thus eliminate or greatly mitigate any new infection, which significantly contributes to having the health status of the stands restored and maintained on a satisfactory level.

\section{CONCLUSIONS}

On the first tested site, the occurrence of fungi primarily depended on the presence of mechanical damage, where this link was quite strong with as much as $73.46 \%$, while the remaining $26.54 \%$ were contingent upon other factors. On the other hand, statistical analysis of the data received on the first site showed that the occurrence of fungi had almost no connection to the presence of abiotic damage (the correlation link was only 3.21\%).

On the second site, there was a statistically significant difference between all columns, as well as between the number of abiotic injuries and the occurrence of fungi. This was not the case on the previous site, but appeared here as a result of a large of number of injuries. The strongest correlation link was the one between the total number of fungi and the mechanical injuries, amounting to $51.88 \%$. The link between the total number of fungi and abiotic injuries was also strong at $47.96 \%$, whereas the links between the number of dangerous and other fungi on one hand and mechanical and abiotic injuries on the other, ranging $26.70 \%$ to 
$36.47 \%$, may be considered significant. This effectively means that the occurrence of fungi on the second site was directly linked to the presence of both mechanical and abiotic injuries.

Based on the results of the comparative analysis of the two sites, the number of injuries may be identified as the determining factor linking the occurrence of fungi and the damage on trees. On sites with fewer injuries the correlation links between the occurrence of fungi and the injuries are less strong, and vice versa.

Careful and proper handling of trees during felling is critical for the health condition of tall beech stands. Every injury sustained by live beech trees during felling opens the door to infection by pathogenic microorganisms. Proper stewardship may minimize the existing infections and thus eliminate or greatly mitigate any new infection, which significantly contributes to having the health status of the stands restored and maintained on a satisfactory level.

\section{REFERENCES}

Bankovic, S., Medarevic, M., Pantic, D., Petrovic, N., Sljukic, B., Obradovic, S. (2000): Growing stock of Republic of Serbia - The situation and problems. Bulletin of Faculty of Forestry No. 100, pp. 7-30

Bankovic, S., Medarevic, M., Pantic, D., Petrovic, N. (2009): National Forest Inventory of the Republic of Serbia - Growing stock of Republic of Serbia. Ministry of Agriculture Forestry and Water Management Serbia - Management of Forests, Belgrade, Serbia, pp. 1244

Ivkovic, S., Markovic, M., Miric, M (2007): Growth and mycelial mass production of wood - decaying fungus Trametes versicolor (Fr.) Pil. and Coniophora puteana (Schum.:Fr.) Karst in controled temperature and $\mathrm{pH}$ conditions. International Scientific Conference "Integral protection of Forests Scientific - Technological platform", Belgrade, 12.12.2007, Book of abstracts, pp 95-96

Karadzic, D. (2003): The most important disease of the beech forests in Serbia. Forestry No. 1-2, pp. 59-72

Karadzic, D, Milijasevic, T. (2005): Beech (Fagus moesiaca /Domin, Mally/ Czeczott.) in Serbia. Monography, Chapter 3, Faculty of Forestry, Belgrade, Serbia, pp 179-196

Koprivica, M, Matovic, B. (2005): Regression equations of volume and volume increment of beech trees in high forests in Serbia. Sustainable Forestry, No. 52-53, pp. 5-17 [in Serbian]

Koprivica, M., Matovic, B., Markovic, N. (2008): Qualitative and assortment structure of high beech stand volume in Severnokucajsko forest area. Forestry, Vol. 60, No. 1-2, pp. 41 52 [in Serbian]

Koprivica, M., Matovic, B., Cokesa, V. (2009): Qualitative structure of volume, volume increment and yield of a beech high stand. Forestry, Vol. 61, Iss. 1-2, pp 95-108

Markovic, N., Koprivica, M., Matovic, B. (2007): Software "Assortment" designed for processing field data. Institute for Forestry, Belgrade, Serbia [in Serbian] 
Markovic, M., Rajkovic, S., Miric, M., Mitic, D., Milovanovic, J., Tabakovic-Tosic, M. (2011a): Colonization of the substrate of wood - decaying fungi Fomitopsis pinicola (Sw.:Fr.) P. Karst. isolated from beech and fir under controlled temperature and $\mathrm{pH}$ conditions. Fresenius Environmental Bulletin, Vol. 20, Issue 3, pp 583-589

Markovic, M., Rajkovic, S., Miric, M., Mitic, D., Rakonjac, Lj. (2011b): Growth conditions of mycelium medicinal mushroom Lentinula edodes (Berk.) Pegl. in the substrate colonization phase”, Scientific Research and Essays, 8 September, Vol 6(19), pp 41334140

Medarevic, M., Bankovic, S., Sljukic, B. (2008): Sustainable Forest Management in Serbia - State and Potentials. Bulletin of the Faculty of Forestry 97, pp 33-56

Miletic, Z., Markovic, M., Tabakovic-Tosic, M. (2006): Effect of Diferent Soil Types on Hazard to Beech Caused by the Fungi in the Genus Nectria in M.U. "Majdan-Kucajna". International. Scientific Conference in occasion of 60 year of operation of Institute of Forestry, Belgrade, Serbia. Sustainable Use of Forest Ecosystems-The Challenge of the $21^{\text {st }}$ Century, 8-10 November, Donji Milanovac, Proceedings, pp. 297-302

Milovanovic, D., Krstic, M., Babic, V. (2004): Significance of productive and social functions for the beech forests in Serbia. Forestry, No 1-2, January-June, pp 105-116

Stojanovic, Lj., Krstic, M. (2003): Basic problems of growing the beech forests. Forestry, vol. 55, No. 1-2, pp 25-38

Tabakovic-Tosic, M., Markovic, M. (2003): Harmful biotic factors in beech copice forests of east Serbia. International scientific conference " 75 years of the Forest Research Institute of Bulgarian Academy of Sciences" , 1-5 October. Sofia. Bulgaria Proceedings of scientific papers 2, pp. 239-246

Vuckovic, M., Stajic, B., Radakovic, N. (2005): Significance of the monitoring diameter increment in terms of bioindication vitality of stems and stands. Forestry, Vol. 57, No. 1-2, pp 1-10

\title{
ANALYSIS OF THE IMPACT OF INJURIES CAUSED BY THE INFLUENCE OF MECHANICAL AND ABIOTIC FACTORS ON THE OCCURRENCE OF HARMFUL FUNGAL ORGANISMS
}

\author{
Miroslava MARKOVIC, Snezana RAJKOVIC, Radoslav RAJKOVIC
}

\section{Summary}

The research was conducted in eastern Serbia, in a hillside beech forest Fagetum moesiacae submontanum of generative origin. The testing was carried out on two sites over 51 testing plots, with a total of 829 trees and 21 species of identified fungi. On the first site it was found that the appearance of fungi primarily depends on the presence of mechanical damage on trees (as much as $73.46 \%$ ), while the presence of abiotic damage has almost no bearing (only $3.21 \%$ ). On the second site there was a strong correlation link between the occurrence of fungi and presence of mechanical damage $-51.88 \%$, as well as between the fungi and abiotic damage $-47.96 \%$.

On the first tested site, the occurrence of fungi primarily depended on the presence of mechanical damage, where this link was quite strong with as much as $73.46 \%$, while the remaining $26.54 \%$ were contingent upon other factors. On the other hand, statistical 
analysis of the data received on the first site showed that the occurrence of fungi had almost no connection to the presence of abiotic damage (the correlation link was only $3.21 \%$ ).

On the second site, there was a statistically significant difference between all columns, as well as between the number of abiotic injuries and the occurrence of fungi. This was not the case on the previous site, but appeared here as a result of a large of number of injuries. The strongest correlation link was the one between the total number of fungi and the mechanical injuries, amounting to $51.88 \%$. The link between the total number of fungi and abiotic injuries was also strong at $47.96 \%$. This effectively means that the occurrence of fungi on the second site was directly linked to the presence of both mechanical and abiotic injuries.

Based on the results of the comparative analysis of the two sites, the number of injuries may be identified as the determining factor linking the occurrence of fungi and the damage on trees. On sites with fewer injuries the correlation links between the occurrence of fungi and the injuries are less strong, and vice versa. The health condition of high beech stands was found to be heavily dependent on careful and proper manipulation during harvesting, while each injury inflicted on a beech live tree during logging opens the door to infection with pathogenic microorganisms.

\title{
АНАЛИЗА УТИЦАЈА ОЗЛЕДА ПРОУЗРОКОВАНИХ ДЕЈСТВОМ МЕХАНИЧКИХ И АБИОТИЧКИХ ФАКТОРА НА ПОЈАВУ ШТЕТНИХ ГЉИВИЧНИХ ОРГАНИЗАМА
}

\author{
Мирослава МАРКОВИћ, Снежана РАЈКОВИЋ, Радослав РАЈКОВИћ
}

\section{Резиме}

Истраживања су вршена у источној Србији, у брдској шуми букве Fagetum moesiacae submontanum, генеративног порекла. Испитивањем је обухваћено два локалитета на 51 огледној парцели, са укупно 829 стабала и констатовано је присуство 21 врста гљива. На првом локалитету констатовано је да појава гљива првенствено зависи од присуства механичких оштећења на стаблима (чак 73,46\%), а готово уопште није у вези са присуством абиотичких оштећења (свега 3,21\%). На другом локалитету постоји јака корелациона веза између појаве гљива и присуства механичких оштећења - 51,88\%, као и између гљива и абиотичких оштећења $47,96 \%$.

На првом испитиваном локалитету, појава гљива првенствено зависи од присуства механичких оштећења - веза је јака, износи чак $73,46 \%$, а осталих $26,54 \%$ зависи од других фактора. Насупрот томе, статистичка анализа добијених података на првом локалитету показује да појава гљива готово да уопште није у вези са присуством абиотичких оштећења (корелациона веза износи свега $3,21 \%$ ).

На другом локалитету постоји значајна статистичка веза између свих колона, па и између броја абиотичких оштећења и појаве гљива, што није био случај са претходно приказаним локалитетом, а што је у овом случају последица великог броја оштећења. Најјача корелациона веза постоји између укупног броја гљива и механичких оштећења и износи 51,88\%. Веза између укупног броја гљива и абиотичких оштећења је такође јака и износи 47,96\%. То практично значи да је појава гљива на другом локалитету, у директној вези са присуством и механичких и абиотичких оштећења.

Ако се посматрају резултати добијени упоредном анализом првог и другог локалитета, може се рећи да је опредељујући фактор који доводи у везу појаву гљива 
и оштећења на стаблима управо број оштећења. На локалитетима са мањим бројем оштећења корелационе везе између појаве гљива и озледа на стаблима су слабије и обрнуто. Констатовано је да за здравствено стање високих букових састојина изузетан значај има пажљиво и правилно манипулисање приликом сече, а свака озледа на буковим дубећим стаблима почињена при сечи је отворен пут за заразу патогеним микроорганизмима. 
